\title{
Wpływ płomienia acetylenu, propanu i metanu do podgrzewania wstępnego na właściwości stali drobnoziarnistej
}

\section{Effect of acetylene, propane and methane flame for preheating on the fine-grained steel properties}

\section{Streszczenie}

Wykonano próby podgrzewania kilku gatunków stali do różnych wartości temperatury, mające na celu określenie skuteczności i wydajności ww. paliw gazowych oraz rozpoznanie ich potencjalnie szkodliwych skutków dla właściwości materiału. Badano możliwość wykorzystania poszczególnych gazów do ogrzewania, suszenia i podgrzewania wstępnego. Omówiono wpływ gazów na tworzenie się wody kondensacyjnej na powierzchni podgrzewanych elementów i w konsekwencji na ich korozję. Najlepszym gazem okazał się acetylen. Badania właściwości mechanicznych oraz próba twardości wykazały, że podgrzewanie nie powoduje szkodliwych skutków dla obrabianych materiałów, a zwłaszcza kruchości wodorowej. Stwierdzono, że podgrzewanie wstępne jest procesem niezbędnym w przetwórstwie stali konstrukcyjnych o podwyższonej i wysokiej wytrzymałości.

\section{Abstract}

The paper presents results of tests of several kinds of steels heating to various temperatures, to determine the effectiveness and efficiency of acetylene, propane and methane flame as gaseous fuels and to identify their potentially harmful effects on the properties of the material. Investigated the possibility of using different gases for heating, drying and preheating. The influence of various gases on the formation of condensation water on the surface of heated elements, and consequently on their corrosion. The most preferred gas was acetylene. The study of the mechanical properties and hardness test showed that the heating does not cause the expected adverse effects on treated materials, particularly hydrogen embrittlement. It was found that pre-heating is necessary in the manufacturing process strengthen structural steels and high strength steels.

\section{Wstęp}

Wykorzystanie w przemyśle materiałów o wysokiej i podwyższonej wytrzymałości jest obecnie kluczowym elementem wytwarzania podzespołów podlegających wysokim naprężeniom w takich dziedzinach jak budownictwo okrętowe i konstrukcje stalowe, w tym konstrukcje przybrzeżno-morskie. Materiały te umożliwiają wytwarzanie elementów o mniejszym przekroju, a przenoszącym te same obciążenia, co oznacza, że mogą mieć mniejszą masę. Zwiększone wykorzystanie drobnoziarnistych stali konstrukcyjnych sprawia, że podgrzewanie wstępne odgrywa coraz większą rolę.

Sven Selling, Ronald Steusloff - Linde Gas.
Podgrzewanie można wykonywać różnymi sposobami i przy użyciu różnych urządzeń. Zwyczajowo podgrzewa się je przy użyciu mat grzewczych, w piecu lub płomieniowo. Dwie pierwsze metody stosowane są do podgrzewania elementów niepoddawanych dalszemu przetwarzaniu. Natomiast płomień wykorzystuje się do podgrzewania międzyoperacyjnego lub jako przygotowanie do mającego nastąpić procesu łączenia lub cięcia. Najczęściej stosowanymi gazami palnymi są: acetylen, propan (LPG ) oraz metan (gaz ziemny). Dostępne, towarzyszące gazy utleniające, to czysty tlen oraz powietrze zasysane $z$ atmosfery i powietrze sprężone.

W artykule przedstawiono próby przeprowadzone na różnych materiałach i w różnej temperaturze podgrzewania. Próby te miały na celu podkreślenie skuteczności zastosowane gazów palnych i rozpoznanie wszelkich, potencjalnie szkodliwych skutków dla właściwości materiału. Następstwem zebrania 
danych miała być optymalizacja wykorzystania paliwa gazowego do określonych zastosowań i zminimalizowanie ryzyka powstania kłopotów materiałowych na dalszych etapach procesu wytwarzania.

\section{Podgrzewanie płomieniowe}

W procesie przetwarzania metali podgrzewanie płomieniowe stosuje się do różnych celów. Zabieg ten stosuje się od operacji, gdzie temperatura wynosi ok. $100^{\circ} \mathrm{C}$, do kształtowania stali na gorąco w temperaturze ok. $1000^{\circ} \mathrm{C}$. W dalszej części artykułu omówiono bardziej szczegółowo obszary wykorzystania płomienia gazowego do podgrzewania osuszającego, podgrzewania wstępnego, czy też obróbki cieplnej. Jest to szczególnie ważne, ponieważ drobnoziarnista stal konstrukcyjna jest obecnie wykorzystywana w coraz większym stopniu, co wymaga odpowiedniej, zarówno wstępnej, jak i późniejszej obróbki cieplnej, jak np. podczas spawania.

\section{Podgrzewanie osuszające}

Podgrzewanie osuszające jest istotnym procesem w przebiegu dalszej obróbki, takich jak cięcie płomieniowe lub spawanie. Zakres temperatury roboczej wynosi $80 \div 120^{\circ} \mathrm{C}$ dla blach grubszych niż $30 \mathrm{~mm}$. Usuwanie wilgociz powierzchniobrabianegoelementu lub złącza spawanego zapobiega powstawaniu wad w późniejszym okresie, takich jak porowatość i pęknięcia, oraz związanej z nimi kosztownej naprawy tych wad po przeprowadzeniu zasadniczego procesu. Uzyskuje się to dzięki wykorzystaniu płomienia acetylenu ze sprężonym powietrzem lub acetylenu z tlenem. Użycie propanu lub metanu daje zazwyczaj przeciwny skutek ze względu na obecność wysokiego stężenia pary wodnej w produktach spalania tych gazów, co powoduje, że do złącza wchodzi dodatkowa wilgoć, pogarszając w ten sposób wyniki spawania.

\section{Podgrzewanie wstępne}

Znaczenie podgrzewania stale wzrasta ze względu na zwiększone zużycie drobnoziarnistej stali konstrukcyjnej. Dlatego ważne jest podgrzanie elementu do wcześniej określonej temperatury w celu spowolnienia procesu chłodzenia, co minimalizuje ryzyko wzrostu twardości i powstania pęknięć. Proces ten jest wyszczególniony i zalecany w licznych arkuszach danych materiałowych dotyczących żelaza i stali. Obszar i temperatura, do której element musi być podgrzany, zależą od różnych czynników, m.in. od grubości obrabianego elementu, rodzaju materiału i metody spawania. Jeśli wartość CET jest wyższa niż 0,40\%, podgrzewanie jest na ogół wymagane dla wszystkich grubości blachy. Norma DIN-EN 1011-2 przedstawia ogólne zasady wyznaczania temperatury podgrzewania wstępnego przy wykorzystaniu równoważnika węgla. Obydwie te kluczowe wartości mają przyczynić się do zapewnienia dostatecznie wysokiej temperatury w obrabianym elemencie, aby zapobiec powstawaniu pęknięć wodorowych w drobnoziarnistej stali konstrukcyjnej. Temperatura jest rejestrowana po przeciwnej stronie źródła ciepła.

\section{Badane materiały}

Badano pięć stali: S460G2+M, S690QL1, P460NL1, S690QL i S960QL.

Stale te stosowane są do budowy zbiorników ciśnieniowych, morskich platform wiertniczych oraz dźwigów. Zostały one podzielone na trzy klasy wytrzymałościowe: $460 \mathrm{~N} / \mathrm{mm}^{2}, 690 \mathrm{~N} / \mathrm{mm}^{2}$ i $960 \mathrm{~N} / \mathrm{mm}^{2}$. Kody na końcu symbolu wskazują stan w momencie dostawy i udarność materiału. Litery QL oznaczają, że stal została dostarczona w stanie odpuszczonym i musi osiągnąć udarność $27 \mathrm{~J}$ w temperaturze $-40^{\circ} \mathrm{C}$. Podobnie QL1 wskazuje, że stal została dostarczona w stanie odpuszczonym, jednak udarność $27 \mathrm{~J}$ została osiągnięta $w$ temperaturze $-60^{\circ} \mathrm{C}$. Udarność $27 \mathrm{~J}$ musi być uzyskana dla próbek, które zostały pobrane poprzecznie do kierunku walcowania. Pozostałe litery NL1 oznaczają, że materiał jest dostępny w stanie normalizowanym po walcowaniu i uzyskuje udarność $27 \mathrm{~J}$ w temperaturze $-40^{\circ} \mathrm{C}$. G2+M oznacza, że materiał był obrabiany termomechanicznie (litera M) i uzyskuje udarność przynajmniej $60 \mathrm{~J}$ w temperaturze $-40^{\circ} \mathrm{C}$ (G2). Te wartości udarności odnoszą się również do próbek pobranych poprzecznie do kierunku walcowania. Wszystkie blachy zostały dostarczone po walcowaniu. Na początku zbadano ich skład chemiczny i najważniejsze właściwości mechaniczne.

\section{Nagrzewanie próbek}

$\mathrm{Na}$ podstawie wcześniej przeprowadzonych prób dokonano ogólnych ustaleń odnośnie prowadzenie procesu wstępnego podgrzewania próbek. Dotyczy to prędkości roboczej przesuwu palnika, która jest utrzymywana na stałym poziomie $0,5 \mathrm{~m} / \mathrm{s}$. Temperaturę podgrzewania wstępnego ustalono na $150^{\circ} \mathrm{C}$ i $300^{\circ} \mathrm{C}$. Ponadto wykorzystano skomputeryzowany układ sterowania numerycznego maszyny w celu zapewnienia jednakowych warunków podgrzewania wszystkich próbek, jak również stałego ruchu oscylacyjnego palnika (rys. 1).

Próbki podgrzewano kolejno acetylenem, a następnie propanem i metanem. Podczas prób utrzymywano stałą odległość palnika od materiału, która wynosiła ok. $2 \div 3 \mathrm{~mm}$.

Zaobserwowano, że płomienie wytwarzane przez propan i metan są mniej intensywne i znacznie mniejsze niż płomień acetylenowy. Te aspekty dają 


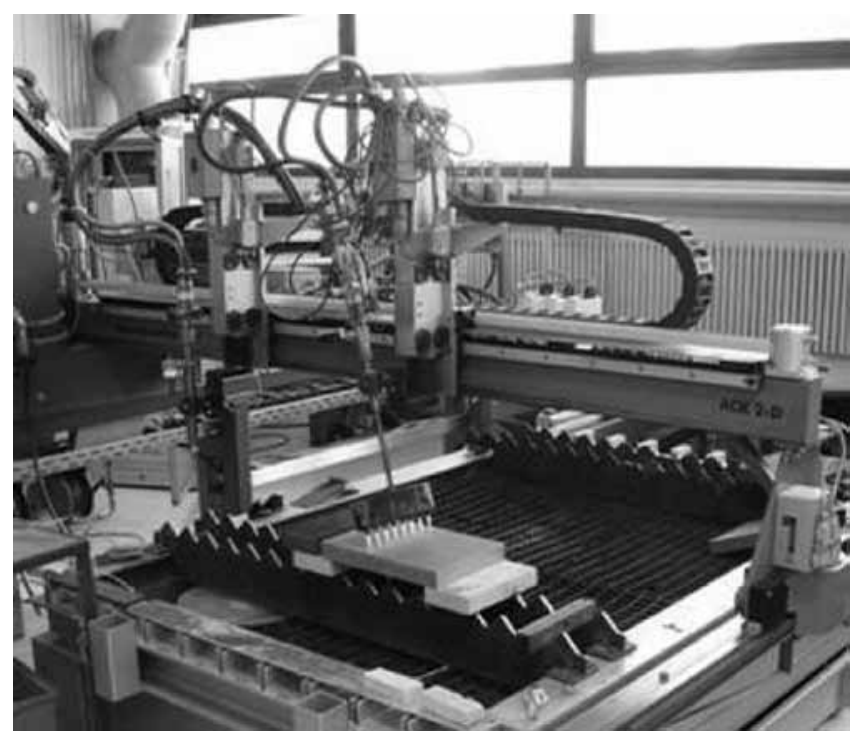

Rys. 1. Stanowisko badawcze

Fig. 1. Testing station

podstawy do twierdzenia, że będą różne czasy nagrzewania dla poszczególnych elementów. Również obserwuje się znaczne różnice pomiędzy rodzajami gazów palnych w kwestii osiąganych wartości temperatury, odczytywanej w punkcie pomiarowym. Wzrost temperatury jest znacznie niższy, gdy ogrzewa się propanem i metanem aniżeli acetylenem. Na przykład ogrzewanie stali $\mathrm{P} 460 \mathrm{NL} 1$ do $150^{\circ} \mathrm{C}$ propanem jest dłuższe o ok. $30 \%$ niż acetylenem. Zastosowanie metanu powoduje dalsze wydłużenie czasu podgrzewania do ok. $40 \%$. Ogrzewanie tej samej stali do $300^{\circ} \mathrm{C}$ powoduje, że różnica czasu dla uzyskania żądanej temperatury wzrasta jeszcze bardziej i wówczas różnica czasu między propanem i acetylenem wynosi ok. $60 \%$, a przy porównaniu metanu z acetylenem ok. $76 \%$. Widoczne jest, że przenikanie ciepła do ogrzewanego elementu, gdy używa się propanu i metanu, powoduje powolne asymptotyczne zbliżanie się do zadanej temperatury, natomiast dużo wyższą temperaturę można osiągnąć przy użyciu acetylenu.

Gdy ogrzewano powierzchnię oczyszczoną strumieniem śrutu, zaobserwowano inne interesujące zjawisko. Możliwe było uchwycenie różnicy w oddziaływaniu płomienia różnych gazów na powierzchnię podgrzewanego elementu $w$ temperaturze pokojowej i podczas dalszego procesu ogrzewania. W przypadku acetylenu, po zapaleniu palnika i jego przejściu przez ogrzewany element, można zauważyć na początku słabo widoczną mgłę wodną. W czasie przebiegu procesu podgrzewania na ogrzewanym elemencie widoczny jest jedynie ślad płomienia. Po przekroczeniu temperatury $200^{\circ} \mathrm{C}$ powoli pojawiają się barwy nalotowe, które stają się coraz intensywniejsze aż do osiągnięcia wymaganych $300^{\circ} \mathrm{C}$. Barwy te pozostają nadal widoczne po ostygnięciu metalu. Są one równomiernie rozłożone od środka na zewnątrz ku brzegom.

Ogrzewanie przy użyciu metanu i propanu przebiega nieco inaczej. Oprócz tego, że proces nagrzewania trwa dłużej, prowadzi on także do korozji powierzchni w trakcie i bezpośrednio po podgrzewaniu. Przy obydwóch gazach następuje natychmiastowe gromadzenie się wody na powierzchni elementu po zapaleniu palnika. Gromadzenie się wody jest znacznie większe w przypadku użycia metanu niż propanu, co prowadzi do wysokiego stopnia korozji powierzchni. Podczas procesu ogrzewania, oprócz tego, że wzrasta temperatura, następuje również osuszanie powierzchni. Woda odparowuje całkowicie gdy temperatura mierzona po przeciwnej stronie niż ta, na którą oddziałuje płomień, osiągnie wartość ok. $75^{\circ} \mathrm{C}$, co oznacza, że temperatura po stronie palnika wynosi przynajmniej $100^{\circ} \mathrm{C}$. Po odparowaniu i osiągnięciu temperatury $150^{\circ} \mathrm{C}$ można zaobserwować widoczny początek korozji powierzchniowej. Gdy ogrzewa się dalej do temperatury $300^{\circ} \mathrm{C}$, pojawiają się barwy nalotowe, które nie tworzą linii jak w przypadku acetylenu, natomiast są rozłożone równomiernie po całej powierzchni.

Analiza krzywych nagrzewania stali S690QL1 dla wszystkich trzech rodzajów gazu wskazuje, że jeśli po przekroczeniu temperatury $150^{\circ} \mathrm{C}$ usunie się płomień, wówczas krzywa natychmiast opada (rys. 2).

Zarówno dla metanu, jak i propanu z powodu małej mocy płomienia i jego niskiej temperatury rejestruje się powolny wzrost temperatury. Ponadto szybkość przenikania ciepła do podgrzewanego elementu jest mniejsza od szybkości odprowadzania ciepła. Dla porównania, użycie acetylenu prowadzi do szybszego wzrostu temperatury. Usunięcie płomienia pokazuje, że w zasadzie następuje ustabilizowanie się temperatury. Dzieje się tak z powodu mocy płomienia, która jest trzylub czterokrotnie większa, co prowadzi do lepszego rozkładu ciepła w ogrzewanym elemencie. Jednakże, właściwość ta słabnie ze wzrostem grubości blachy.

Ponadto, gdy podgrzewa się acetylenem stal S460G2+M, wymaganą temperaturę osiąga się szybciej niż w przypadku trzech pozostałych stali: P460NL1, S690QL, S960QL.

Jeśli rozpatrzymy teraz strukturę płomieni poszczególnych gazów, możemy zauważyć, że jądro płomienia acetylenu jest dużo większe niż propanu i metanu. W przeciwieństwie, w przypadku metanu i propanu dużo większa jest kita płomienia. Wynikiem tej różnicy

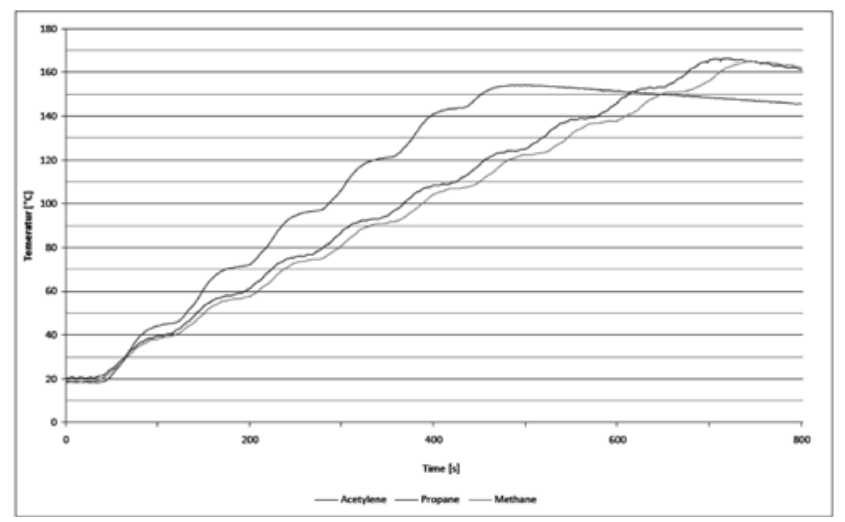

Rys. 2. Krzywe nagrzewania stali S690QL1

Fig. 2. S690QL1 steel heating curves 
jest to, że gdy podgrzewa się acetylenem, ciepło jest wprowadzane do elementu szybciej niż gdy używa się innych gazów. Podczas prób ustalono, że powierzchnia elementu próbnego nie jest przegrzewana w żadnym punkcie, gdyż prowadziłoby to do zmiany struktury. Ponadto, podczas wszystkich tych prób należało unikać uszkodzenia powierzchni. W związku z tym wyrywkowo mierzono temperaturę na powierzchni przy użyciu pirometru. Przez krótki czas, gdy płomień przechodził przez element, temperatura na powierzchni była o ok. $50^{\circ} \mathrm{C}$ wyższa. Gdy płomień przesuwał się dalej, temperatura na powierzchni szybko wyrównywała się $\mathrm{z}$ temperaturą na dolnej stronie elementu.

\section{Ocena prób i dyskusja wyników}

Badane próbki poddano szczegółowej analizie i porównano z odpowiednimi badaniami materiałów w celu zobrazowania zmian we właściwościach mechanicznych. Z badanych elementów pobrano różne próbki. Były to próbki do rozciągania pobrane w kierunku podłużnym i poprzecznym oraz próbki do udarowych prób zginania w kierunku poprzecznym. Pobrano także próbki do badań mikrograficznych. Dalsze próbki pobrane z kilku badanych elementów przeznaczone były do oznaczenia w nich zawartości wodoru.

\section{Wpływ rodzaju gazu na proces korozji}

Z tych procesów można wyciągnąć wnioski odnośnie tworzenia się warstwy korozyjnej na skutek oddziaływania metanu i propanu. Proces korozji jest intensyfikowany na skutek wcześniejszego czyszczenia strumieniowo-ściernego powierzchni, ponieważ warstwy rdzy i zgorzeliny opóźniają proces korozji przez hamowanie przepływu elektronów. Zjawisko to regulowano dzięki zastosowaniu do podgrzewania płomienia od neutralnego do lekko utleniającego. Spalanie następuje w dwóch etapach, ponieważ nie ma wystarczającej ilości tlenu, aby mogło przebiegać w reakcji jednostopniowej. Poniższe równania ilustrują dwustopniowy proces spalania przy zastosowaniu propanu - równania (1) i (2) oraz acetylenu - równania (3) i (4), a także (2):

$$
\begin{aligned}
& \mathrm{C}_{3} \mathrm{H}_{8}+4 \mathrm{O}_{2} \rightarrow 2 \mathrm{CO}+4 \mathrm{H}_{2} \mathrm{O}+\mathrm{CO}_{2} \\
& 2 \mathrm{CO}+\mathrm{O}_{2} \rightarrow 2 \mathrm{CO}_{2} \\
& \mathrm{C}_{2} \mathrm{H}_{2}+\mathrm{O}_{2} \rightarrow 2 \mathrm{CO}^{2}+2 \mathrm{H} \\
& 2 \mathrm{H}+\mathrm{O} \rightarrow \mathrm{H}_{2} \mathrm{O}
\end{aligned}
$$

Równania reakcji z zastosowaniem metanu pominięto, ponieważ reakcje te przebiegają podobnie jak przy spalaniu propanu.

Z równania (1) pokazuje, że podczas spalania propanu wytwarza się czterokrotnie więcej wody niż przy spalaniu acetylenu - równania (3) i (4). Po zapaleniu palnika następuje gromadzenie się wody wydzielonej z płomienia, w wyniku kondensacji pary wodnej na powierzchni elementu. Proces ten jest widoczny, gdy stosuje się propan i metan, natomiast przy użyciu acetylenu następuje bardzo silne usuwanie wody z powierzchni. Wysoka temperatura płomienia i bardzo wyraźne jądro płomienia powodują szybkie odparowanie skroplonej wody. Ponadto, szybkie przekraczanie punktu rosy zapobiega skraplaniu pary wodnej. Punkt rosy spalin pochodzących ze spalania acetylenu wynosi $42^{\circ} \mathrm{C}$, co również przyczynia się do zapobiegania osadzaniu się skroplin na powierzchni elementu. Wynika z tego że nie występuje dostateczna ilość wilgoci, która jest potrzebna do wydzielenia jonów $\mathrm{OH}^{-}$w celu zainicjowania procesu korozji. Oznacza to, że powierzchnia ogrzewanego elementu pozostaje metalicznie połyskująca.

Oddziaływania te dotyczą także metanu i propanu. Obydwa te gazy dają słaby płomień i wykazują względnie niską prędkość przepływu w porównaniu z acetylenem. Ponadto, wytwarzają płomień z dużą ilością. Usuwa to wodę przed płomieniem, ale może prowadzić do osadzania się skroplin po bokach palnika. Wyższy punkt rosy spalin $\left(55^{\circ} \mathrm{C}\right.$ dla propanu i $59^{\circ} \mathrm{C}$ dla metanu) sprzyja także powstawaniu skroplin na powierzchni elementu. Potrzebny jest dłuższy czas do osiągnięcia tych wartości temperatury na elemencie, co umożliwia przebieg procesu korozji.

Poniższy przykład pokazuje w wartościach liczbowych, ile wody wytwarza się podczas spalania $1 \mathrm{~m}^{3}$ paliwa gazowego. Na podstawie równań $(1 \div 4)$ widać wyraźnie, że uzyskuje się 4 mole wody $(4 \cdot 18 \mathrm{~g})$ w wyniku procesu spalania 1 mola propanu (44 g). Natomiast tylko $1 \mathrm{~mol}$ wody powstaje ze spalenia $1 \mathrm{mola}$ acetylenu $\left(\mathrm{C}_{2} \mathrm{H}_{2}-26 \mathrm{~g}\right)$. Proporcja dla propanu wynosi $1: 1,636$, a dla acetylenu 1:0,6923. Ponadto, propan ma gęstość $1,871 \mathrm{~kg} / \mathrm{m}^{3}$, a acetylen $1,1 \mathrm{~kg} / \mathrm{m}^{3}$ w stanie gazowym pod ciśnieniem 1 bara, w temperaturze $15^{\circ} \mathrm{C}$. Te warunki wstępne uważane są za wystarczające dla naszych badań. Spalając $1 \mathrm{~m}^{3}$ propanu, wytwarza się 3,061 kg wody, natomiast acetylenu tylko $0,7615 \mathrm{~kg}$. Jednakże woda ta nie wydziela się w $100 \%$ w postaci skroplin. Po przekroczeniu odpowiednich punktów rosy woda odparowuje i ulatnia się do atmosfery. Nasze badanie uwzględnia całkowite spalanie. O $17 \%$ więcej wody uwalnia się, gdy podgrzewa się metanem aniżeli propanem.

\section{Podsumowanie}

Próby podgrzewania pokazują, że płomień acetylenu ze sprężonym powietrzem jest najbardziej efektyw-

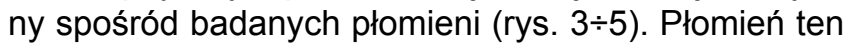
umożliwiał szybsze osiągnięcie wymaganej temperatury w porównaniu z płomieniem uzyskanym z dwóch pozostałych gazów. Podczas gdy różnica czasu potrzebnego do podgrzania elementów propanem i metanem do $150^{\circ} \mathrm{C}$ - w porównaniu z acetylenem - wynosiła tylko $30 \%$ i $40 \%$, to przy nagrzewaniu do $300^{\circ} \mathrm{C}$ powiększyła się odpowiednio do $60 \%$ i $76 \%$. Ponadto podgrzewanie 
do $300^{\circ} \mathrm{C}$ metanem i propanem wykazało, że gazy te prędko osiągają swoją maksymalną, możliwą do uzyskania temperaturę, co poznaje się po płaskim przebiegu krzywej. W przypadku acetylenu, natomiast, prawie liniową postać wznoszącej się krzywej obserwuje się jeszcze nawet przy $300^{\circ} \mathrm{C}$. Jednym z najważniejszych punktów uwydatnionych dzięki naszym badaniom jest tworzenie się wody kondensacyjnej na powierzchni podgrzewanego elementu. Wynika to z wysokiej zawartości wodoru w metanie i propanie. Woda odparowuje z powierzchni, gdy element się ogrzewa, niemniej jednak wiele śladów korozji pozostaje. Na dalszych etapach przetwarzania materiału, takich jak spawanie lub obróbka powierzchniowa, może to prowadzić do zniszczenia wytworzonej konstrukcji wcześniej niż uprzednio założono w obliczeniach lub badaniach.

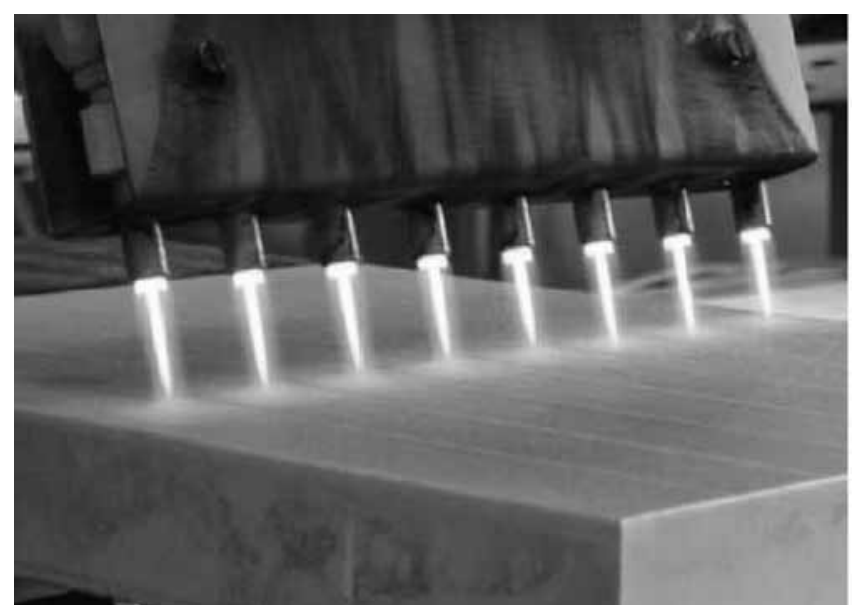

Rys. 3. Płomień acetylenu ze sprężonym powietrzem

Fig. 3. Acetylene-compressed air flame

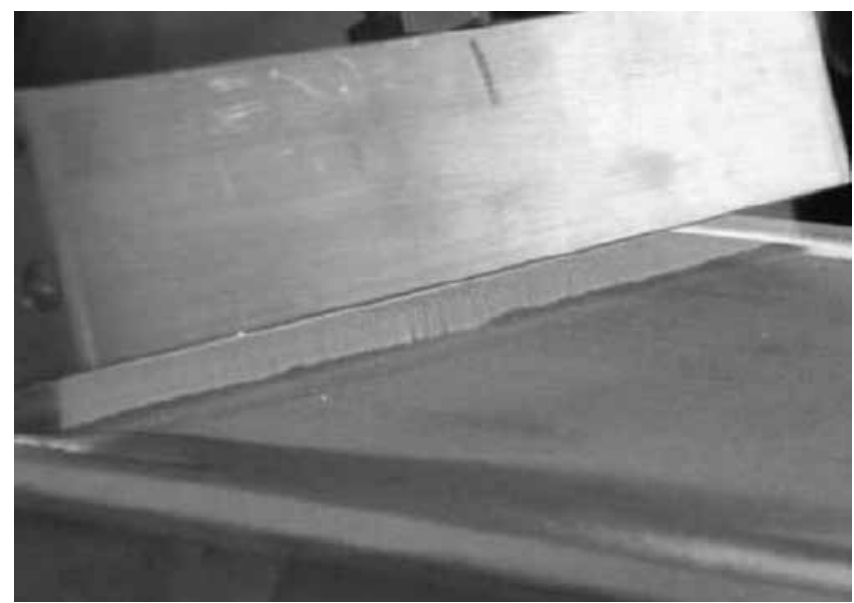

Rys. 4. Płomień propanu ze sprężonym powietrzem

Fig. 4. Propane-compressed air flame

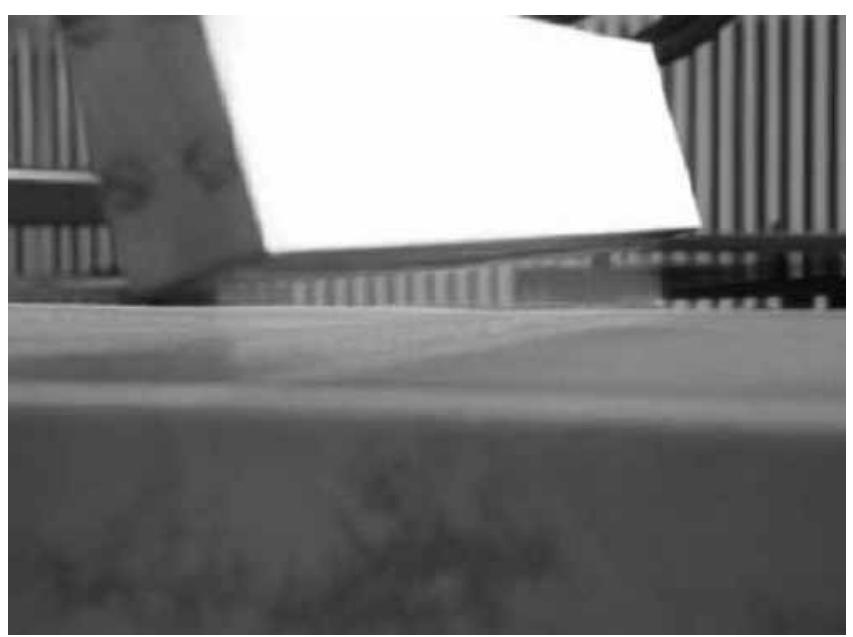

Rys. 5. Płomień metanu ze sprężonym powietrzem Fig. 5. Methane-compressed air flame

Badanie poszczególnych gazów palnych i ich wpływu na proces ogrzewania pokazuje, że acetylen jest najbardziej korzystny. Po ukończeniu prób nagrzewania przeanalizowano właściwości mechaniczne elementów. Wykazały one przede wszystkim, że można wykluczyć dyfuzję wodoru do wnętrza podgrzewanego przedmiotu. Ponieważ powierzchnia nie stapia się, a wodór nie jest obecny w postaci atomowej, nie ma możliwości wzbogacenia materiału w wodór pod powierzchnią materiału.

Inne próby mające na celu ocenę właściwości mechanicznych wykazały również, że podgrzewanie nie powoduje przewidywanych szkodliwych skutków dla obrabianych elementów. Pomimo podgrzewania różnymi gazami i do różnych temperatur wytrzymałość na rozciąganie pozostawała jednakowa. Próby udarności w niższych temperaturach wykazały, że podgrzewanie nie ma wpływu na udarność. Próba twardości również nie wykazała żadnych zmian związanych z rodzajem gazu palnego i stosowaną temperaturą.

Można zatem stwierdzić, że podgrzewanie wstępne jest procesem niezbędnym w przetwórstwie stali konstrukcyjnych o wysokiej i podwyższonej wytrzymałości. Nawet jeśli nie ma jeszcze żadnych zmian w mikrostrukturze lub we właściwościach mechanicznych na tym etapie pracy, pewne okoliczności należy rozważyć zawczasu, aby mieć pewność, że praca na późniejszych etapach będzie przebiegać bezpiecznie i bez komplikacji. Istotne jest rozważenie rodzaju gazu i postaci czynnika utleniającego. 